\title{
RADIOGRAPHIC EXAMINATION PROCEDURE AS NON DESTRUCTIVE TESTING METHOD IN PROCESS PIPING
}

\author{
Rachmasari Pramita Wardhani \\ Mechanical Engineering Department, Tridharma University, Balikpapan \\ e-mail: rrrachmasari@gmail.com
}

\begin{abstract}
Industry must have good quality for their services or products. One of the things that their have done is how to get the customer's belief in their brand. Quality in every part has become the main case. Most of the companies in industry use metals as material to support their services. When the goods have been processed, it must continue with the testing. This is to prove that the goods have gone through the formation process fill in standard quality which required by the customer. There are two types of testing known as destructive testing and non-destructive testing. There are some of ways of non destructive testing methods on metals inspection has been applied in testing the quality of goods. Such as visual test, magnetic particle test, liquid penetrant, eddy current test, ultrasonic test, radiographic test in metals testing. Nondestructive testing (NDT) is the process of inspecting, testing, or evaluating materials, components or assemblies for discontinuities, or differences in characteristics without destroying the serviceability of the part or system. Radiographic Testing (RT) is a nondestructive examination technique that involves the use of either x-rays or gamma rays to view the internal structure of a component. In the petrochemical industry, Radiographic Testing is often used to inspect machinery, such as pressure vessels and valves, to detect for flaws. RT is also used to inspect weld repairs. Compared to other NDT techniques, radiography has several advantages. It is highly reproducible, can be used on a variety of materials, and the data gathered can be stored for later analysis.
\end{abstract}

Keywords—radiographic, non-destructive testing, piping, examination

\begin{abstract}
Abstrak
Industri harus memiliki kualitas yang baik untuk layanan atau produk mereka. Salah satu hal yang telah mereka lakukan adalah bagaimana mendapatkan kepercayaan pelanggan terhadap merek mereka. Kualitas di setiap bagian telah menjadi kasus utama. Sebagian besar perusahaan di industri menggunakan logam sebagai bahan untuk mendukung layanan mereka. Ketika barang sudah diproses, harus dilanjutkan dengan pengujian. Ini untuk membuktikan bahwa barang yang sudah melalui proses formasi memenuhi standar kualitas yang diminta oleh pelanggan. Ada dua jenis pengujian yang dikenal sebagai pengujian destruktif dan pengujian non-destruktif. Ada beberapa cara metode pengujian non destruktif pada pemeriksaan logam yang telah diterapkan dalam menguji kualitas barang. Seperti uji visual, uji partikel magnetik, penetran cair, uji arus eddy, uji ultrasonik, uji radiografi dalam pengujian logam. Nondestructive testing (NDT) adalah proses inspeksi, pengujian, atau evaluasi bahan, komponen atau rakitan untuk diskontinuitas, atau perbedaan karakteristik tanpa merusak kemudahan servis bagian atau sistem. Radiographic Testing (RT) adalah teknik pemeriksaan tak rusak (NDE) yang melibatkan penggunaan sinar-x atau sinar gamma untuk melihat struktur internal suatu komponen. Dalam industri petrokimia, Pengujian Radiografi sering digunakan untuk
\end{abstract}


memeriksa mesin, seperti bejana tekan dan katup, untuk mendeteksi adanya kekurangan. RT juga digunakan untuk memeriksa perbaikan lasan. Dibandingkan dengan teknik NDE lainnya, radiografi memiliki beberapa keunggulan.

Kata kunci-radiografi , pengujian tak merusak, perpipaan, pengujian

\section{INTRODUCTION}

In many manufacturing world, Industry must have good quality for their services or products. One of the things that their have done is how to get the customer's belief in their brand. Quality in every part has become the main case. Most of the companies in industry use metals as material to support their services, some metals will be processed by welding processing. so welding process is needed to support the work. When the goods have been processed, it must continue with the testing. This is to prove that the goods have gone through the formation process fill in standard quality which required by the customer. There are two types of testing known as destructive testing and nondestructive testing. To take minimalizing the risk of losses on goods and cost, the most common examination or testing selected and implemented by the company is nondestructive testing.

There are some of ways of non destructive testing methods on metals inspection has been applied in testing the quality of goods. Such as visual test, magnetic particle test, liquid penetrant, eddy current test, ultrasonic test, radiographic test in metals testing. In this case the writer is interested in choosing to study the radiographic inspection procedure as a nondestructive test in the piping process.

\section{EXPERIMENTAL PROCEDURES}

There are two way in material testing in manufacture. Namely destructive testing and non destructive testing, it is necessary applied in process because the test will help to determine the nature of materials used. Materials used in industry such as iron, stainless steel, aluminum, etc. which will be tested before use.
The first test for inspection goods that we have known is destructive testing or examination. Destructive testing or examination is accomplished by forcing the material to fail under various load factors. The destructive testing method is used to find mechanical properties of materials such as tensile strength, yield strength, hardness, impact toughness, elongation, etc. The method determines the point of failure of the material. This test is carried out under severe operational circumstances, and conditions are continual till the material breaks. The method of destructive testing ensures the reliability of material or mechanical part when subjected to the load. It also identifies whether the part or device produced encompass the required properties.

Nondestructive testing (NDT) is the process of inspecting, testing, or evaluating materials, components or assemblies for discontinuities, or differences in characteristics without destroying the serviceability of the part or system. So, when the inspection or test is completed the part can still be used. Today, modern nondestructive tests are used in manufacturing, fabrication and in-service inspections to ensure product integrity and reliability, to control manufacturing processes, lower production costs and to maintain a uniform quality level. in case of construction, NDT is used to ensure the quality of materials and joining processes during the fabrication and erection phases, and in-service ,NDT inspections are used to ensure that the products in use continue to have the integrity necessary to ensure their usefulness and the safety of the public.

Nondestructive Testing (NDT) consists of a variety of non-invasive inspection techniques used to evaluate material properties, components, or entire process units. The 
techniques can also be utilized to detect, characterize, or measure the presence of damage mechanisms (e.g. corrosion or cracks). NDT is also commonly referred to as nondestructive examination (NDE), nondestructive evaluation (NDE), and nondestructive inspection (NDI).

Many NDT techniques are capable of locating defects and determining the features of the defects such as size, shape, and orientation. The purpose of NDT is to inspect a component in a safe, reliable, and cost effective manner without causing damage to the equipment or shutting down plant operations. This is in contrast to destructive testing where the part being tested is damaged or destroyed during the inspection process. NDT can be performed during or after manufacture, or even on equipment that is in service. In manufacturing, NDT inspections determine if parts are fit for a desired function. In other words, parts are inspected to ensure they will last a certain amount of time or cycles before failure. During operation, NDT inspections can be used to assess the current damage state of equipment, monitor damage mechanisms, and make informed decisions for remaining equipment life evaluation.

NDT methods can generally be classified into two categories: conventional and advanced.

Conventional NDT Techniques

Conventional methods are techniques that have matured over the course of decades and in this time, have become well-documented in codes, standards, and best practices. The setup and procedure of a conventional technique is typically simpler in comparison to advanced methods.

Table 1. commonly used NDT

\begin{tabular}{|c|c|c|}
\hline technique & Capabilities & limitations \\
\hline Visual & $\begin{array}{l}\text { Macroscopic } \\
\text { surface flaws }\end{array}$ & $\begin{array}{l}\text { Small flaws are } \\
\text { difficult to detect, } \\
\text { no subsurface } \\
\text { flaws }\end{array}$ \\
\hline Microscopy & $\begin{array}{l}\text { Small surface } \\
\text { flaws }\end{array}$ & $\begin{array}{l}\text { Not applicable to } \\
\text { larger structure: ni } \\
\text { subsurface flaws }\end{array}$ \\
\hline Radiography & $\begin{array}{l}\text { Subsurface } \\
\text { flaws }\end{array}$ & $\begin{array}{l}\text { Smallest defect } \\
\text { detectable is } 2 \% \\
\text { of the thickness , } \\
\text { radiation } \\
\text { protection. }\end{array}$ \\
\hline Dye & Surface flaws & No subsurface \\
\hline
\end{tabular}

\begin{tabular}{|l|l|l|}
\hline penetrant & & $\begin{array}{l}\text { flaws not porous } \\
\text { materials }\end{array}$ \\
\hline Ultrasonic & $\begin{array}{l}\text { Subsurface } \\
\text { flaws }\end{array}$ & $\begin{array}{l}\text { Material must be } \\
\text { good conductor of } \\
\text { sound }\end{array}$ \\
\hline & & $\begin{array}{l}\text { Limited } \\
\text { subsurface } \\
\text { capability, only } \\
\text { for ferromagnetic } \\
\text { materials }\end{array}$ \\
particle & $\begin{array}{l}\text { Surface and } \\
\text { layer flaws }\end{array}$ & $\begin{array}{l}\text { Difficult to } \\
\text { interpret, } \\
\text { expensive } \\
\text { equipments }\end{array}$ \\
\hline Eddy current & $\begin{array}{l}\text { Surface and } \\
\text { flaws }\end{array}$ & \\
\hline
\end{tabular}

NDT inspections are an integral part of the oil and gas and petrochemical industries, along with several other industries, like chemicals, aerospace, automotive, and defense. The goal is to detect flaws in components to reduce failure and increase reliability.

NDT is often prescribed by codes and standards for the fabrication of components, safety critical parts, and in-service equipment. Therefore, it is critical for all refinery, chemical plant, gas plant, and pipeline owners to have thorough understanding and experience in the interdisciplinary field of NDT. In addition to the factors listed above (Industry Application section) personnel should continuously develop knowledge about evolving technology and performing up-todate procedures. Specific codes, standards, specifications, regulations, and recommended practices may depend on the country and industry performing NDT. The following is a list of organizations (standards bodies) that develop and publish industrial codes, standards, and recommended practices for NDT methods relating to the oil and gas and chemical processing industries:

1. The American Society for Nondestructive Testing (ASNT)

2. ASTM International

3. American Society of Mechanical Engineers (ASME)

4. American Petroleum Institute (API)

5. American Welding Society (AWS)

6. National Board of Boiler and Pressure Vessel Inspectors (NBBI)

7. International Organization for Standardization (ISO). 


\section{European Committee for Standardization (CEN). \\ 9. European Pressure Equipment Directive (PED).}

Radiographic Testing (RT) is a nondestructive examination technique that involves the use of either $\mathrm{x}$-rays or gamma rays to view the internal structure of a component. In the petrochemical industry, Radiographic Testing is often used to inspect machinery, such as pressure vessels and valves, to detect for flaws. RT is also used to inspect weld repairs. Compared to other NDT techniques, radiography has several advantages. It is highly reproducible, can be used on a variety of materials, and the data gathered can be stored for later analysis. Radiography is an effective tool that requires very little surface preparation.

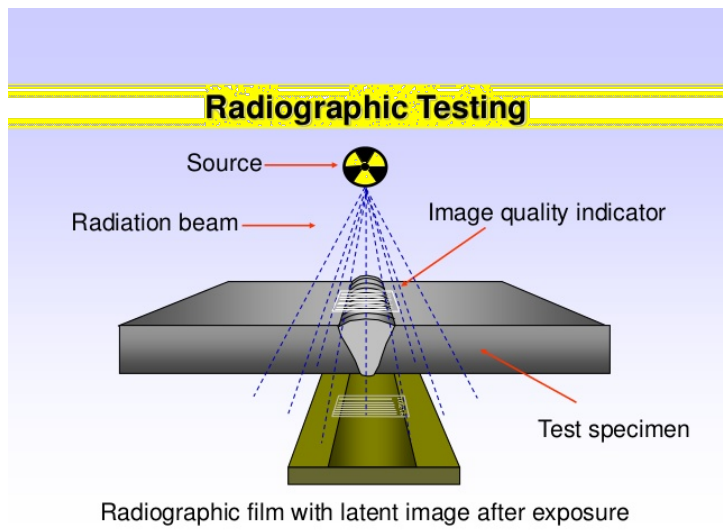

Picture 1 Radiographic Testing

\section{Conventional Radiography}

Conventional radiography uses a sensitive film which reacts to the emitted radiation to capture an image of the part being tested. This image can then be examined for evidence of damage or flaws. The biggest limitation to this technique is that films can only be used once and they take a long time to process and interpret.

\section{Digital Radiography}

Unlike conventional radiography, digital radiography doesn't require film. Instead, it uses a digital detector to display radiographic images on a computer screen almost instantaneously. It allows for a much shorter exposure time so that the images can be interpreted more quickly. Furthermore, the digital images are much higher quality when compared to conventional radiographic images. With the ability to capture highly quality images, the technology can be utilized to identify flaws in a material, foreign objects in a system, examine weld repairs, and inspect for corrosion under insulation. The four most commonly utilized digital radiography techniques in the oil \& gas and chemical processing industries are computed radiography, direct radiography, real-time radiography, and computed tomography.

1) Computed Radiography

Computed radiography (CR) uses a phosphor imaging plate that replaces film in conventional radiography techniques. This technique is much quicker than film radiography but slower than direct radiography. CR requires several extra steps compared to direct radiography. First, it indirectly captures the image of a component on a phosphor plate, then converts the image into a digital signal that can be visualized on a computer monitor. Image quality is fair but can be enhanced using appropriate tools and techniques (i.e, adjusting contrast, brightness, etc. without compromising integrity). It's important to know how tools, such as adjusting contrast, effect the image. Care should also be taken to make sure minor defects are not hidden after enhancements are made.

\section{2) Direct Radiography}

Direct Radiography (DR) is also a form of digital radiography and very similar to computed radiography. The key difference lies in how the image is captured. In DR, a flat panel detector is used to directly capture an image and display that image on a computer screen. Although this technique is fast and produce higher quality images, it is more costly than computed radiography.

\section{3) Real-Time Radiography}

Real-time radiography (RTR), like it's name suggests, is a form of digital radiography that occurs in real time. RTR works by emitting radiation through an object. These rays then interact with either a special phosphor screen or flat panel detector containing microelectronic sensors. The interaction between the panel and the radiation creates a digital image that can be viewed and analyzed in real time. 
The brighter areas on the image are a result of higher levels of radiation that contact the screen. This corresponds to the thinner or less dense section of the component. Conversely, darker areas are a result of less radiation interacting with the screen and indicate where the component is thicker. Aside from being able to make the images available more quickly and analyze them in real time, RTR has several other advantages. One being that digital images don't require physical storage space and thus are easier to store, transfer, and archive than film.

4) Computed Tomography

Computed tomography (CT) is a technique that takes hundreds to thousands (depending on the size of the component) of 2D radiography scans and superimposes them to create a 3D radiographic image.

In an industrial setting, CT can be achieved in two ways. In one method, the component to be inspected remains stationary while the radiation source and $\mathrm{x}$-ray detector rotate around the component. This technique is more likely to be utilized for large components. The second method consists of the radiation source and $\mathrm{x}$-ray detector remaining stationary while the component is rotated 360 degrees. This second technique is more useful when the component is small or has complex geometry.

\section{RESULTS AND DISCUSSION}

There are some Special pipe inspection tests also carried out on the material when it is going to be used in aggressive environments. These tests will ensure that pipe material is able to withstand in such aggressive environments. During manufacturing, different types of pipe inspection and testing are done to ensure the quality of the pipes.

To ensure product quality, during and after the production certain pipe inspection and nondestructive testing are performed on the body \& weld of the pipe. These pipe inspection will check whether any physical defects are present in the pipe/weld, which may affect its performance during the service. These testing are,
1) Flux leakage examination or Magnetic flaw detection.

2) Eddy current

3) Ultrasonic - can be done on full body or only for weld seam

4) Radiography (Only for Weld)

5) Magnetic particle test for pipe ends \& weld seam

6) Positive Material Identification.

During manufacturing, the company also carries out Pipe visual Inspection which is one of the most effective inspection methods used to check overall product quality. on visual inspection, the product can inspect the entire product, check surface imperfections such as mechanical markings, laminates, tears or other visual imperfections and also check welding defects such as porosity, pieces, uneven welding beads, and excess or lack of contents of the material welding. Acceptance of these imperfections complies with applicable ASTM standards.

Radiographic testing or RT, can be used to detect internal defects in castings, welds or forgings by exposure the construction to x-ray or gamma ray radiation. Defects are detected by differences in radiation absorption in the material as seen on a shadow graph displayed on photographic film or a fluorescent screen.

in conducting RT tests, personnel who carry out radiographic examinations must meet the requirements and Certified according to the company where it was written Qualification and Certification Practices for NDT SOPs NDT Personnel - 001, Rev.5, which is in accordance with SNT-TC-1A, 2006 Edition.

The examiner must have an annual vision test with corrections if necessary, to allows him to read Jaeger J2's standard chart at a distance of not less than $305 \mathrm{~mm}$ (12 inches). The person will be able to distinguish and distinguish the contrast between the colors used.

Safety (She Instruction)

Radiography personnel shall always wear a film badge. A fully charged pocket dosimeter 
may also be used whenever in or near a radiation area.

In addition, they shall always maintain an operable survey meter in the radiation area and use it to verify that the area is safe. The area ware radiography is being carried out shall be roped off (or otherwise barricaded) and signboard in English to prevent accidental entry by unauthorized personnel. An operator shall remain near the crank of the source holder while an exposure is being made in order to retract in the event of unauthorized personnel entry into the radiation area. During times of high work activity, a whistle shall be sounded prior to commencement of radiography to inform workforce of imminent radiation exposure. There are SHE instruction for safety working:

- Always use PPE such as Safety shoes, hand glove, safety glass, and helmet.

- Watch out for slippery and falling apart.

- Watch out for the hazard around the areas. Stop the activities and report to client and supervisor for unsafe working condition.

- Put barricade or safety line in the safe distance during the radiographic

- Use fall protection equipment if working above $2 \mathrm{~m}$. See Radiant SHE SOP

- Follow the company (RU.Tbk) WPI-NDT006 (Radiation Protection Program) if working with Radiation Materials.

- Collect all waste and put it in agreed place.

Procedure

Surface material must meet applicable requirements material specifications, with additional conditioning, if necessary, by processes suitable for the level produced by radiography. The picture due to surface irregularities cannot cover or confuse with pictures of each discontinuity.

Welds are ripples or weld surface irregularities on both insides (where accessible) and outside must be removed by the appropriate process for in such a way that the resulting radiographic image is due to anything surface irregularities cannot be covered or confused with images any discontinuity.
Surface preparation will be the responsibility of the Client beforehand.

Radiographic request.

Security (he's instructions).

Radiography personnel must always wear a film badge. Fully loaded pocket dosimeters can also be used anytime in or near the radiation area. In addition, they must always maintain survey meters that can be operated in the radiation area and use it to verify that the area is safe.

Radiography of the area of ware being carried out must be tied with a rope (or vice versa barricades) and signage in English to prevent unintentional entry by unauthorized persons personnel. The operator must remain near the source crank.

Table 2 Film Type of Radiographs

\begin{tabular}{|c|c|c|c|c|}
\hline \multirow{2}{*}{ Film type } & \multicolumn{3}{|c|}{ Description } & \multirow{2}{*}{ Film used } \\
\cline { 2 - 4 } & Speed & Contrast & Graining & \\
\hline & Medium & Very High & Extra Fine \\
I & High & MX125, D4 \\
II & HA400, D7 \\
\hline
\end{tabular}

in film size ,The film sizes to be used as follows: 4" X 10" , 4" X 15". Smaller sizes may be used to suit the pipe configuration; there is $100 \%$ coverage of the pipe joint with the numbers of exposure.

\section{Intensifying Screens.}

Lead intensifying screen of $0.125 \mathrm{~mm}$ thickness shall be placed in close contact at front and back of each film.

The density of the film is transmitted through radiographic images adjacent to welds must be at least 1.8 to watch a single film radiographs made with $\mathrm{X}$-ray sources and a minimum of 2.0 or radiographs made with gamma rays. For composite display multi-exposure film, each film from a composite set must have a minimum density of 1.3. Maximum density must be 4.0 for one single or composite display. Tolerances of 0.05 in density are permitted for variations between them densitometer reading. If the radiographic density is anywhere through the area of interest vary more than minus $15 \%$ or plus $30 \%$ of the density through adjacent to the 
wire designated from the IQI wire, inside minimum / maximum allowable density range is determined in 6.5.1., then Additional IQI must be used for each area or exceptional area the radiograph reoccurred. The density of the film must be determined with a densitometer or a calibrated film thickness strips.

Placement of Penetrameters.

1) The penetrameter (s) shall be placed on the film side in contact with part being examined.

2) The Penetrameter (s) shall be placed so that length of the wires is perpendicular to the length of weld.

3) A complete panoramic exposure using individual cassettes, four penetrameters shall be placed at 90 degrees to each other.

4) Penetrameter shall be placed at lease two, one shall be within 1 inches ( $25 \mathrm{~mm}$ ) of the end of the film length to be interpreted and other shall be at the center of the film, for SWE/SWV or DWE/SWV if density variation unsatisfied.

5) For DWE/DWV procedure, one penetrameter shall be placed on the source side of the pipe and adjacent to the weld so that its image is not superimposed onto the weld image.

The selection of wire penetrameter used and the designated wire diameter shall be as specified in table bellow.

Table 3 selection of wire penetrometer

\begin{tabular}{|c|c|c|c|c|}
\hline \multirow{3}{*}{$\begin{array}{c}\text { Nominal Single- } \\
\text { Wall Thickness } \\
\text { Range, Inch }\end{array}$} & \multicolumn{4}{|c|}{$\begin{array}{l}\text { Penetrameter Selection } \\
\end{array}$} \\
\hline & \multicolumn{2}{|c|}{ Source Side } & \multicolumn{2}{|c|}{ Film Side } \\
\hline & $\begin{array}{c}\text { Wire-Type } \\
\text { Essential } \\
\text { Wire }\end{array}$ & $\begin{array}{c}\text { I.Q.I } \\
\text { Series }\end{array}$ & $\begin{array}{c}\text { Wire-Type } \\
\text { Essential } \\
\text { Wire }\end{array}$ & $\begin{array}{l}\text { I. Q. I. } \\
\text { Series }\end{array}$ \\
\hline Up to 0.25 Incl. & 5 & Set A & 4 & Set A \\
\hline Over 0.25 to 0.375 & 6 & Set B & 5 & Set A \\
\hline Over 0.375 to 0.50 & 7 & Set B & 6 & Set B \\
\hline Over 0.50 to 0.75 & 8 & Set B & 7 & Set B \\
\hline Over 0.75 to 1.00 & 9 & Set B & 8 & Set B \\
\hline Over 1.00 to 2.50 & 10 & Set B & 9 & Set B \\
\hline Over 1.50 to 2.00 & 11 & Set C & 10 & Set B \\
\hline Over 2.00 to 2.50 & 13 & Set C & 11 & Set C \\
\hline Over 2.00 to 4.00 & 14 & Set C & 12 & Set C \\
\hline
\end{tabular}

NOTE:

a. For DWE/SWV techniques, the diameter of the wire shall be based on the nominal single wall thickness of the specimen. b. For weldments, the diameter of wire employed shall be based on the nominal single wall thickness, as referenced in an above,including the thickness of weld reinforcement.

Tabel 4 Penetrameter sizes wire diameter

TABLE A1.1

PENETRAMETER SIZES WIRE DIAMETER, in. (mm)

\begin{tabular}{lc}
\hline \multicolumn{1}{c}{ SET A } & SET B \\
\hline $0.0032(0.08)^{4}$ & $0.010(0.25)$ \\
$0.004(0.1)$ & $0.013(0.33)$ \\
$0.005(0.13)$ & $0.016(0.41)$ \\
$0.0063(0.16)$ & $0.020(0.51)$ \\
$0.008(0.2)$ & $0.025(0.64)$ \\
$0.010(0.25)$ & $0.032(0.81)$ \\
\hline \multicolumn{1}{c}{ SET C } & SET D \\
\hline $0.032(0.81)$ & $0.100(2.5)$ \\
$0.040(1.02)$ & $0.126(3.2)$ \\
$0.050(1.27)$ & $0.160(4.06)$ \\
$0.063(1.6)$ & $0.20(5.1)$ \\
$0.080(2.03)$ & $0.25(6.4)$ \\
$0.100(2.5)$ & $0.32(0.81)$ \\
\hline \multicolumn{4}{|c}{ The 0.0032 wire may be used to establish a special quality } \\
level as agreed upon between the purchaser and the supplier.
\end{tabular}

A single wall exposure/single wall view (swe/swv) in radiographic technique.

Technique shall be used for radiography whenever practical. When it is not practical to use a single wall exposure/single wall view, a double wall exposure/single wall view (DWE/SWV) technique shall be used. Single-Wall Exposure/Single-Wall View (SWE/SWV). The radiation passes through only one wall of the weld (material), which is viewed for acceptance on the radiograph. An adequate number of exposures shall be made to demonstrate that the required coverage has been obtained.

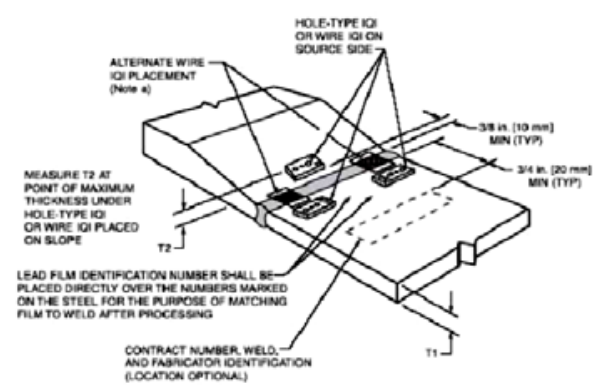

Picture 2 Radiographic technique 
Source-Weld-Film Arrangement

\begin{tabular}{c|c}
\hline End View & Side View \\
\hline
\end{tabular}

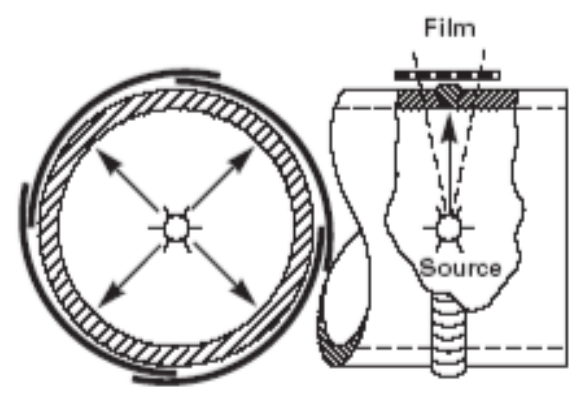

Expcesure Arrangement - A

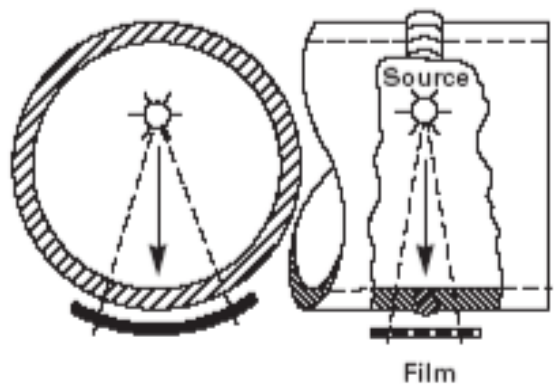

Exposure Arrangement - B

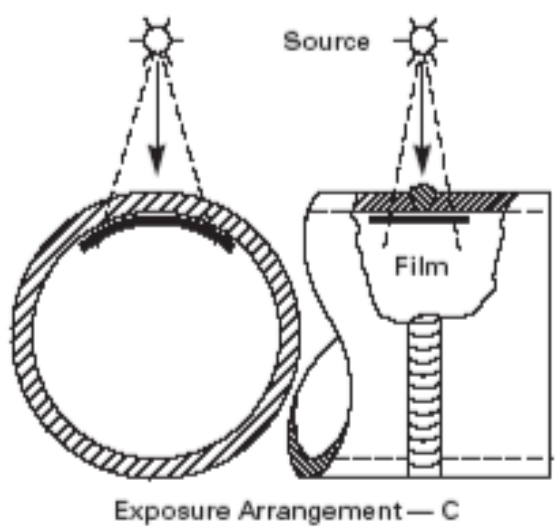

Picture 3 A,B,C Single wall exposure technique T-271.1

Radiographi viewing =single wall Exposure Technique =single-Wall T-271.1 Placement : sourece side T-277.1 (a) Film side T-277.1 (b)
Location marker placement : either side $\mathrm{T}$ 275.3 ; T-275.1(c)

\section{CONCLUSION}

In maintaining radiograph quality. All radiographs must be free of mechanical, chemical or other defects as long as they do not cover and are not confused with images of any discontinuities in the area of interest of the radiographed object. Such stains include, but are not limited to:

-Fogging,

-Processing defects such as scratches, watermarks or chemical stains.

-Scratches, finger marks, curls, dirt, static marks, stains or tears.

-Loss of detail due to poor screen for movie contacts.

-The indication is wrong because the screen is broken.

-False indications due to incorrect identification cause not to be used.

-Not enough overlap on weld length.

A radiographic appearance must be carried out under complete dry conditions below underground background lighting with an intensity that will not cause problems reflection, shadow or glare on the radiograph.

The film viewer for radiographic interpretation must provide an adequate source of light for the essential penetrometer wire becomes visible for the specified density range. The audience must provide a variable intensity light source.

\section{REFERENCES}

Bardal, E, and Drugli, J.M (2004), Corrosion Detection and Diagnosis, in Materials Science and Engineering.

Callister W.D. Jr., (2000), Introduction to Materials Science and Engineering, $5^{\text {th }}$ Edition, pp. 223-233. John Wiley and Sons Inc. New York, USA.

Kulkarni, P.G. Valdya, P.R. Shah, B.K. (2005). Validation of protocols for Corrosion and Deposit Evaluation 
pipes by Radiography. Mumbai, India.

Alexander Boateng, Dr. K.A. Danso, Dr. C.P.K. Dagadu , 2013, NonDestructive Evaluation Of Corrosion On Insulated Pipe Using Tangential Radiographic Technique,

Sachin Thorat, Non destructive testing , https://learnmech.com/nondestructive-testing-ndt-testingprocedure-of-ndt/ access on 29 September 2019.

Anonym, https://inspectioneering.com/tag/radi ography access on 29 September 2019 